\title{
Pengembangan LKPD Berbasis Pendekatan Contextual Teaching Learning untuk Membangun Kemampuan Berpikir Kritis Peserta Didik pada Tema Global Warming
}

\author{
Novita*, Siti Romlah Noer Hodijah, Annisa Novianti Taufik \\ Program Studi Pendidikan IPA, FKIP, Universitas Sultan Ageng Tirtayasa \\ *Email: novita.muldan@gmail.com
}

DOI: https://doi.org/10.33369/pendipa.6.1.278-284

\begin{abstract}
This study aims to develop student worksheets with based a contextual teaching learning approach to build students' critical thinking skills on the theme of global warming. The type of research used in this research is research and development by adopting a modified research procedure from Sugiono and has several stages, namely potential problems, data collection, product design and product validity. The instrument used is in the form of a questionnaire validation sheet consisting of material expert validation including aspects assessed are material/content aspects, language aspects, presentation aspects and media expert validation consisting of media/graphic aspects. The results of research and development show the validation level of students' worksheets with based contextual teaching learning approaches to build students' critical thinking skills on the global warming theme seen from overall, it is included in the very valid category with a score of $82 \%$ from assessmen the experts.
\end{abstract}

Keywords: Student Worksheets; Contextual Teaching Learning; Critical thinking; Global Warming; Validity.

\section{ABSTRAK}

Penelitian ini bertujuan untuk mengembangkan lembar kerja peserta didik berbasis pendekatan contextual teaching learning untuk membangun kemampuan berpikir kritis peserta didik pada tema global warming. Jenis penelitian yang digunakan pada penelitian ini adalah penelitian dan pengembangan (research and development) dengan mengadopsi prosedur penelitian dari sugiono yang dimodifikasi dan memiliki beberapa tahapan yaitu potensi masalah, pengumpulan data, desain produk dan validitas produk. Instrument yang digunakan adalah berupa lembar angket. validasi yang terdiri dari validasi ahli materi diantaranya aspek yang dinilai adalah aspek materi/isi, aspek bahasa, aspek penyajian dan validasi ahli media terdiri dari aspek media/kegrafikan. Hasil penelitian dan pengembangan menunjukan tingkat validasi lembar kerja peserta didik berbasis pendekatan contextual teaching learning untuk membangun kemampuan berpikir kritis peserta didik pada tema global warming dilihat dari secara keseluruhan termasuk kedalam kategori sangat valid dengan nilai $82 \%$ dari penilaian para ahli.

Kata kunci: Lembar Kerja Peserta Didik; Contextual Teaching Learning; Berpikir Kritis; Global Warming, Validitas.

\section{PENDAHULUAN}

Bahan ajar sangat penting digunakan oleh guru IPA dalam proses pembelajaran. Pentingnya bahan ajar untuk pembelajaran IPA yaitu mempermudah guru IPA mengarahkan peserta didik seperti tujuan pembelajaran dan menumbuhkan potensi peserta didik yang dibantu melalui bahan ajar yang mendukung tercapainya tujuan pembelajaran, sedangkan pengertian bahan ajar sendiri yaitu seperangkat materi yang disusun secara sistematis yang disiapkan dan digunakan guru untuk membantu melakukan kegiatan belajar mengajar di kelas (Prastowo, 2011).

Kemampuan berpikir kritis peserta didik salah satunya bisa ditumbuhkan melalui lembar kerja peserta didik. Kemampuan berpikir kritis merupakan kemampuan berpikir secara logika (masuk akal) dan reflektif tertuju pada keyakinan dan keputusan yang akan dilaksanakan (Ennis, 2011). Pada abad 21 pembelajaran, kemampuan berpikir kritis menjadi salah satu pilihan utama yang harus dimiliki oleh peserta didik. Pada sederajat pendidikan umum sebagai tata hidup dan kehidupan kepribadian manusia yang 
berkaitan dengan kehidupan bermasyarakat serta lingkungan hidup lainnya (Burhanuddin, 2016).

Melalui kemampuan berpikir kritis peserta didik dapat mengamati pendapat orang lain yang benar dan yang kurang benar berdasarkan kebenaran ilmiah dan pengetahuan, sehingga peserta didik tidak ragu dan bisa memutuskan serta menilai mana yang salah dan yang benar untuk diterima dan diaplikasikan dalam kehidupan sehari-hari (Majid, 2015).

Berdasarkan wawancara dengan guru IPA yang ada di SMPN 10 Cilegon dan MTSN 5 Serang dapat disimpulkan bahwa guru IPA telah menggunakan lembar kerja peserta didik sebagai bagian dari proses pembelajaran. Guru IPA telah menyusun sendiri lembar kerja peserta didik, namun belum sesuai dengan kurikulum yang berlaku, karena diantara materi yang ada didalamnya belum terintegrasi sehingga keterpaduan IPA belum muncul, lembar kerja peserta didik belum adanya praktikum hanya berisi pertanyaan-pertanyaan tentang materi bidang kajian kimia sedangkan bidang kajian yang lain tidak ada dan selain itu belum menyisipkan indikator berpikir kritis, hal ini membuat peserta didik belum mampu membangun kemampuan berpikir kritis diantaranya peserta didik belum dapat membedakan apakah informasi yang di peroleh bisa diterima dengan baik atau tidak, belum mampu menyelesaikan permasalahan apa yang ada dalam pembelajaran dan tampilan lembar kerja peserta didik hanya terdapat pertanyanpertanyan yang harus dijawab oleh peserta didik dan selain itu belum ada praktikum terkhusus pada tema global warming.

Pendekatan yang dapat diterapkan dalam mengembangkan lembar kerja peserta didik yang mampu membangun keterampilan berpikir kritis yaitu pendekatan CTL. Pendekatan Contextual Teaching Learning (CTL) adalah pendekatan pembelajaran yang mampu merangsang munculnya kemampuan berpikir kritis Peserta didik. Pendekatan CTL merupakan suatu proses pembelajaran yang melibatkan peserta didik dalam aktivitas penting yang membantu mereka mengaitkan pelajaran akademis dengan konteks kehidupan nyata yang mereka hadapi (Fatturahman, 2012). Keunggulan LKPD pendekatan Contextual Teaching Learning bisa melatih kemampuan berpikir kritis, berperan pada pembelajaran yang efektif dan berhubungan dengan kehidupan nyata (Shoidah dkk, 2012).

Tujuh komponen dasar dalam menggunakan pendekatan CTL yang harus diperhatikan oleh guru, yaitu (1)konstruktivisme, (2)menemukan, (3)bertanya, (4)masyarakat belajar, (5)pemodelan, (6)refleksi, (7)penilaian autentik. Ketujuh komponen dasar CTL ini sangatlah sinkron dengan upaya memunculkan kemampuan berpikir kritis peserta didik, terutama pada komponen (1) bertanya, (2) menemukan, (3) refleksi (Syahbana, 2012).

Ciri-ciri kemampuan berpikir kritis adalah mengenal masalah dan mampu menyikapi masalah dengan berpikir secara rasional dan mampu menyelesaikan masalah dengan keputusan yang tepat, dapat menganalisis, mengorganisasikan, menggali fakta yang ada dan mampu menarik kesimpulan dengan benar dan sistematis untuk menyelesaikan permasalahan dalam kehidupan sehari-hari (Sulistiana, 2016). Berpikir kritis bertujuan untuk membangun kemampuan dan kecenderungan seseorang untuk membuat keputusan yang masuk akal yang didasarkan pada bukti-bukti dan untuk mencapai pemahaman yang mendalam yang mengarahkan peserta didik menyelesaikan permasalahan dalam kehidupan sehari-hari (Prasmeswari, 2018 ).

Keterpaduan yang digunakan dalam penelitian ini adalah keterpaduan tipe Webbed. Model webbed adalah model pembelajaran yang menggabungkan beberapa KD yang terdiri dari beberapa materi dalam sebuah tema, kemudian tema yang digunakan sebagai pemersatu setiap materi pembelajaran baik fisika, kimia, biologi maupun ilmu lingkungan dan menciptakan suasana yang sangat menyenangkan bagi peserta didik (Marselina, dkk, 2020)

Tema yang digunakan dalam penelitian yaitu Global Warming. Dalam tema Global Warming terdapat beberapa materi dalam bidang kajian IPA (Fisika, Biologi, Kimia, IPBA). Kompetensi dasar (KD) yang digunakan dalam penelitian ini diantaranya yaitu, KD 3.3 Zat dan Karakteristiknya, KD 3.4 Suhu dan Kalor, KD 3.7 Ekosistem, dan KD 3.8 Pencemaran Lingkungan. Pemilihan tema Global Warming dikarenakan, materi yang ada di dalam tema tersebut membuat peserta didik mampu menganalisis sebab akibat Global Warming, mencari tahu bagaimana mekanisme terjadinya 
Global Warming, dan bagaimana upaya untuk mencegah terjadinya Global Warming dan peserta didik mampu untuk berpikir kritis dalam merumuskan masalah dan mencari solusi untuk pemecahan permasalahan dalam kehidupan sehari-hari yang berkaitan dengan tema Global Warming.

Tujuan penelitian pengembangan diharapkan peserta didik mampu membangun kemampuan berpikir kritis melalui bahan ajar yaitu lembar kerja peserta didik pendekatan contextual teaching learning untuk membangun kemampuan peserta didik pada tema global warming.

\section{METODE PENELITIAN}

Subjek penelitian dan pengembangan lembar kerja peserta didik pada kelas VII A. Penelitian dilakukan di kampus Untirta, di SMPN 10 CILEGON dan di MTSN 5 SERANG tahun ajaran 2020-2021 semester genap yang berlokasi di jalan Ki Kahal Link. Pringori Kel. Suralaya Kec. Pulomerak Kota Cilegon 42439, dan Jl. Ki. M. Idris No. 2 Sumuranja Kec. Pulo Ampel Kab. Serang. Waktu dimulai dari bulan Agustus sampai September 2021. Instrumen yang digunakan pada penelitian ini adalah instrument angket yang digunakan untuk memvalidasi LKPD.

Metode penelitian yang digunakan yaitu penelitian dan pengembangan menurut sugiono (2017) yang telah dimodifikasi oleh peneliti menjadi empat tahap yaitu potensi dan masalah, pengumpulan data, desain produk dan validasi produk.

\section{HASIL DAN PEMBAHASAN}

Produk yang dihasilkan pada penelitian dan pengembangan ini adalah berbentuk lembar kerja peserta didik berbasis pendekatan contextual teaching learning untuk membangun kemampuan berpikir kritis peserta didik pada tema global warming. Penelitian dan pengembangan dilakukan dengan menggunakan prosedur menurut (Sugiono, 2017). Metode yang digunakan adalah untuk menghasilkan suatu produk yang disertai pengujian produk untuk mengetahui tingkat validasi produk. Produk akan divalidasi oleh para ahli yang telah disesuaikan dengan kebutuhan peneliti, yang terdiri dari beberapa tahapan diantaranya:

\section{Potensi dan Masalah}

Potensi dan masalah merupakan suatu permasalahan yang ada daerah tertentu dan memiliki potensi untuk dikembangkan menjadi lebih baik. Untuk mengetahui potensi dan masalah pada penelitian ini dilakukan dengan cara melakukan wawancara dan observasi secara langsung ke SMPN 10 CILEGON dan MTSN 5 SERANG untuk melakukan analisis kebutuhan.

A. Analisis Kebutuhan

Analisis kebutuhan dilakukan untuk mengetahui permasalahan apa yang ada di lapangan sehingga peneliti dapat mengembangkan penelitian sesuai dengan permasalahan yang ada salah satunya yaitu dengan cara menganalisis lembar kerja peserta didik, menganalisis kurikulum, menganalisis materi dan menganalisis tujuan lembar kerja peserta didik.

1. Analisis Lembar Kerja Peserta Didik

Berdasarkan hasil wawancara yang telah dilakukan di SMPN 10 CILEGON dan MTSN 5 SERANG lembar kerja peserta didik yang digunakan masih sederhana terlihat dari lembar kerja peserta didik yang hanya terdapat pertanyaan-pertanyaan dalam bidang kajian kimia sedangkan bidang kajian yang lain belum ada dan praktikum belum ada dikarenakan tidak adanya alat dan bahan yang mendukung untuk praktikum. Praktikum sangatlah penting dalam pembelajara IPA karena membaut peserta didik terlibat langsung dalam pembelajaran dan menerapkan materi yang diperoleh dengan praktik secara langsung disekolahan, sehingga berakibat kepada peserta didik yang sulit untuk memahami materi dan pengaplikasian materi dalam kehidupan sehari-hari sehingga peserta didik mengalami kesulitan untuk menumbuhkan kemampuan berpikir kritits (Widha, dkk : 2018).

Lembar kerja peserta didik berbasis pendekatan contextual teaching learning diharapkan mampu membangun kemampuan berpikir kritis peserta didik. Penggunaan LKP berbasis pendekatan contextual teaching learning dengan tujuan peserta didik mampu mengaplikasikan dan menghubungkan materi yang diperoleh dalam pembelajaran dengan kehidupan sehari-hari (Syahbana, 2012) melalui bahan ajar salah satunya yaitu lembar kerja 
peserta didik yang dapat mempermudah peserta didik belajar dikelas maupun dirumah.

\section{Analisis Kurikulum}

Berdasarkan hasil wawancara yang telah dilakukan lembar kerja peserta didik yang digunakan belum sesuai dengan kurikulum K13 revisi 2017 yang diharuskan memiliki keterpaduan, Pembelajaran IPA di SMP menurut kurikulum 2013 revisi 2017 yaitu pembelajaran IPA yang seharusnya menggunakan keterpaduan antar materi baik dari segi materi fisika, kimia, biologi dan IPBA. Untuk menghasilkan keterpaduan antar materi dibutuhkan suatu tema yang dapat memadukan semua kajian bidang materi. Pada penelitian ini menggunakan tema global warming karena tema global warming merupakan isu yang aktual dan sejalan dengan pembelajaran yang secara kontektual. Tema global warming menggunakan model keterpaduan webbed karena keterpaduan yang pembelajarannya menggunakan tema sebagai acuannya, sehingga materi yang satu dengan yang lainnya dapat dikaitkan dengan tema. Kompetensi dasar yang digunakan yaitu kompetensi dasar 3.3 (zat dan karakteristiknya), 3.4 (suhu dan kalor), 3.7 (ekositem), dan 3.8 (pencemaran lingkungan) (Ike yulia, 2017).

\section{Analisis Materi}

Berdasarkan wawancara yang dilakukan materi yang digunakan dalam lembar kerja peserta didik sebelumnya hanya diambil dari aspek kimia yaitu tentang gas karbon dioksida. Belum adanya aspek biologi, fisika, dan IPBA. Dimana seharusnya pembelajaran IPA memadukan antar bidang kajian diantaranya fisika, kimia, biologi dan ilmu lingkungan (IPBA).

Lembar kerja peserta didik yang dikembangkan menggunakan tema global warming memiliki beberapa bidang kajian materi yaitu dalam bidang kimia pada materi zat gas, bidang fisika materi suhu dan perpindahan kalor, bidang kajian biologi materi interaksi antara makhluk hidup dengan lingkungan, dan bidang IPBA materi pencemaran udara.

4. Tujuan Lembar Kerja Peserta Didik

Tujuan pengembangkan bahan ajar berupa lembar kerja peserta didik berbasis pendekatan Contextual Teaching Learning diharapkan mampu membangun kemampuan berpikir kritis peserta didik pada tema global warming yang diharuskan memiliki kemampuan berpikir kritis sesuai dengan pembelajaran pada abad 21 dan peserta didik mampu mengaplikasikan materi yang diperoleh dengan kehidupan sehari-hari, mampu memutuskan keputusan yang benar, sehingga peserta didik dapat menyelesaikan permasalahan yang dihadapi dalam kehidupan nyata (Surahman, 2014 )

\section{Pengumpulan Data}

Setelah menganalisis potensi dan masalah yang ada selanjutnya adalah pengumpulan data. Pengumpulan data digunakan untuk mengumpulkan berbagai informasi yang diperoleh untuk mengembangkan lembar kerja peserta didik. Berdasarkan wawancara dan observasi yang telah dilakukan peneliti mengetahui informasi tentang permasalahan lembar kerja peserta didik yang digunakan pada pembelajaran IPA tema global warming. Sehingga peneliti merancang lembar kerja peserta didik yang dibutuhkan untuk menyelesaikan permasalahan yang ada dengan cara menganalisis materi sesuai kurikulum K13 revisi 2017, memilih KD dan materi yan akan digunakan, menganalisis komponen CTL yang digunakan untuk membangun kemampuan berpikir kritis sesuai dengan kajian pustaka yang didalamnya memuat (kontruktivisme, menemukan, bertanya, masyarakat belajar, pemodelan, penilaian nyata), merancang desain produk dan mendesain produk yang akan digunakan sesuai dengan arahan dan masukan pembimbing.

\section{Desain Produk}

Setelah melakukan pengumpulan data, peneliti melakukan perencanaan awal dalam pembuatan produk berupa LKPD. Lembar kerja peserta didik dirancang dengan pemilihan $\mathrm{KD}$ sesuai dengan tema global warming, merumuskan tujuan pembelajaran sesuai $\mathrm{KD}$, merancang beberapa komponen yang digunakan dimulai dari cover, kata pengantar, petunjuk penggunaan LKPD, struktur materi (Kompetensi Inti, Kompetensi Dasar, Indikator dan Tujuan pembelajaran), Komponen CTL dalam LKPD, Daftar isi, Identitas sekolah, Materi, dan Langkah-langkah komponen pendekatan CTL, Kunci jawaban, Daftar pustaka.

Tahapan contextual teaching learning pada lembar kerja peserta didik yang 
dikembangkan yaitu kontruktivisme, menemukan, bertanya, masyarakat belajar, pemodelan, refleksi dan penilaian nyata yang berhubungan dengan menumbuhkan kemampuan berpikir kritis yang dapat menyelesaikan permasalahan dalam kehidupan nyata (Syahbana, 2012)

Lembar kerja peserta didik dirancang dalam bentuk cetak dan didalam pembelajaran terdapat praktikum dimana pembelajaran IPA tema global warming melakukan 2 kali pertemuan. Kegiatan di lembar kerja peserta didik bukan hanya praktikum dan diskusi melainkan dengan kegiatan yang ada peserta didik mampu membangun kemampuan berpikir kritis dan dapat menyelesaikan permasalahan dalam kehidupan sehari-hari.

\section{Validasi Produk}

Validasi produk adalah suatu cara yang digunakan untuk mengetahui tingkat validasi lembar kerja peserta didik yang divalidasi oleh para ahli, validasi lembar kerja peserta didik menggunakan lembar angket yang bertujuan untuk mengetahui sejauh mana tingkat validasi LKPD yang dikembangkan, validasi produk dilakukan untuk mereview kekurangan dan kelebihan lembar kerja peserta didik, untuk memberikan masukan berupa saran/komentar sehingga dapat diperbaiki kembali sesuai arahan para ahli agar memenuhi kriteria baik dari aspek isi/materi, aspek bahasa, aspek penyajian dan aspek media sehingga lembar kerja peserta didik dapat digunakan untuk proses belajar mengajar peserta didik. (Yana, 2019: 366)

Angket diberikan kepada para ahli untuk memvalidasi lembar kerja peserta didik yang memiliki 4 aspek penilaian yaitu aspek isi/materi, aspek bahasa, aspek penyajian dan aspek media. Lembar kerja peserta didik divalidasi oleh 3 ahli materi dan 3 ahli media. Validator ahli materi terdiri dari 1 dosen IPA dari Universitas Sultan Ageng Tirtayasa Ibu Dwi Indah Suryani, M.Pd, dan 2 guru dari SMPN 10 CILEGON dan MTSN 5 SERANG yaitu Bapak Masrudin, S.Pd dan dan Bapak Aan Dawam S.T yang dilakukan secara daring melalui wa dan email oleh dosen dan offline dengan guru dengan cara mendatangi sekolah secara langsung dan dilakukan pada bulan agustus.

Sedangkan validator ahli media divalidasi oleh 3 ahli media yaitu 1 dosen IPA dari Universitas Sultan Ageng Tirtayasa Bapak Adi Nestiadi, M.Pd, dan 2 guru dari SMPN 10 CILEGON dan MTSN 5 SERANG yaitu Bapak Masrudin, S.Pd dan dan Bapak Aan Dawam S.T yang dilakukan secara daring melalui wa dan email oleh dosen dan offline dengan guru dengan cara mendatangi sekolah secara langsung dan dilakukan pada bulan agustus. Data yang diperoleh berupa data kuantitatif yaitu data penilaian angket dari para ahli dan data kualitatif yaitu saran dan masukan dari para ahli.

Berikut tabel hasil validasi produk.

Tabel 1 Hasil Validasi Produk

\begin{tabular}{c|c|c|c}
\hline No & $\begin{array}{c}\text { Aspek yang } \\
\text { dinilai }\end{array}$ & $\begin{array}{c}\text { Persen } \\
\text { tase }\end{array}$ & kriteria \\
\hline 1 & $\begin{array}{c}\text { Aspek } \\
\text { Materi/isi }\end{array}$ & $81 \%$ & Valid \\
\hline 2 & Aspek Bahasa & $80 \%$ & Valid \\
\hline 3 & $\begin{array}{c}\text { Aspek } \\
\text { Penyajian }\end{array}$ & $85 \%$ & $\begin{array}{c}\text { Sangat } \\
\text { valid }\end{array}$ \\
\hline 4 & $\begin{array}{c}\text { AspekMedia/ } \\
\text { Kegrafikan }\end{array}$ & $84 \%$ & $\begin{array}{c}\text { Sangat } \\
\text { valid }\end{array}$ \\
\hline Jumlah keseluruhan \\
"sangat valid"
\end{tabular}

Berdasarkan hasil analisis data yang diperoleh dari penilaian angket para ahli materi dan media dapat dilihat pada tabel 1 bahwa pengembangan lembar kerja peserta didik berbasis pendekatan contextual learning teaching untuk membangun kemampuan berpikir kritis peserta didik pada tema global warming dapat dinyatakan "sangat valid" dengan catatan "dapat digunakan dengan sedikit revisi"

Berikut merupakan penjelasan per aspek yang divalidasi oleh ahli.

\section{a. Aspek Penilaian Materi/Isi}

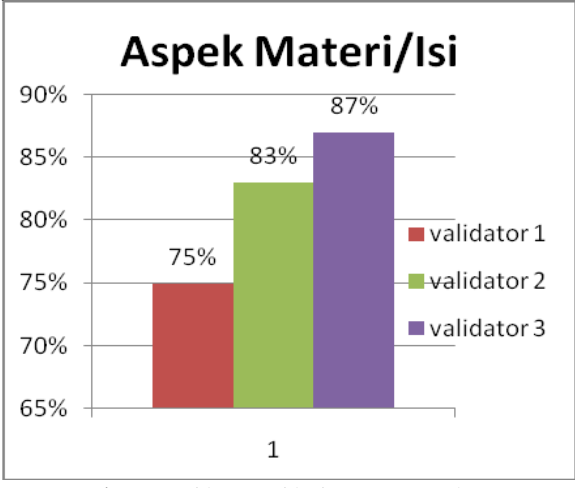

Gambar 1. Hasil Penilaian Aspek Materi/Isi 
Berdasarkan hasil validasi penilaian aspek materi/isi oleh ketiga ahli memperoleh kriteria "valid" karena lembar kerja peserta didik penilaian aspek materi yang sudah sesuai dengan KD dan tujuan pembelajaran K13 2017, konten materi sangat akurat sesuai dengan perkembangan zaman yang pada saat ini isu global warming semakin menyebar luas bukan hanya di Indonesia melainkan dunia, komponen contextual teaching learning yang selaras dengan membangun kemampuan berpikir kritis peserta didik.

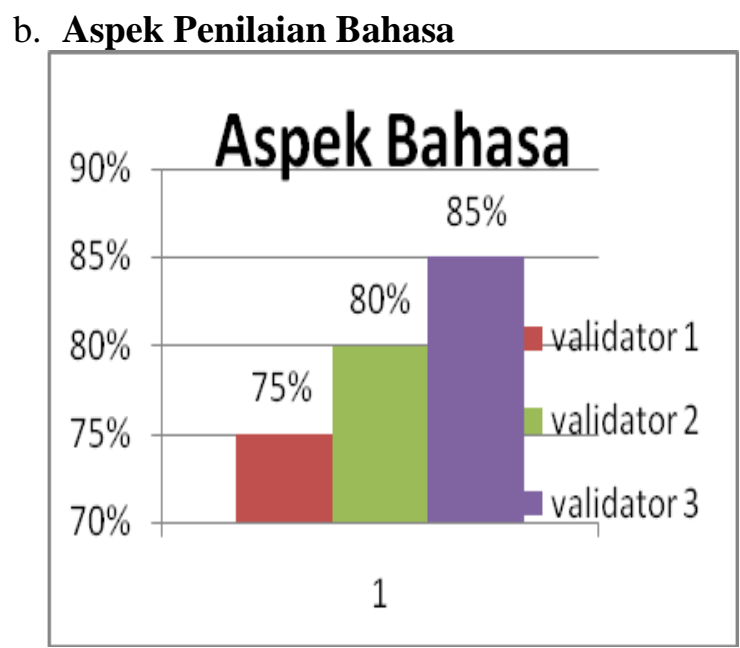

Gambar 2. Hasil Penilaian Aspek Bahasa

Berdasarkan hasil validasi penilaian aspek bahasa oleh ketiga ahli memperoleh kriteria "valid" karena lembar kerja peserta didik dilihat dari aspek bahasa yang sudah sesuai, dilihat dari bahasa yang digunakan sudah saling berhubungan salah satunya pada materi yang memuat langkah-langkah pendekatan contextual teaching learning yang mampu mendorong kemampuan berpikir kritis, bahasa yang digunakan mudah dipahami karena sesuai dengan perkembangan peserta didik, serta informasi yang ada mudah diterima dengan baik oleh peserta didik dan bahasa yang digunakan sesuai dengan kaidah bahasa Indonesia yang baik dan benar.

\section{c. Aspek Penilaian Penyajian}

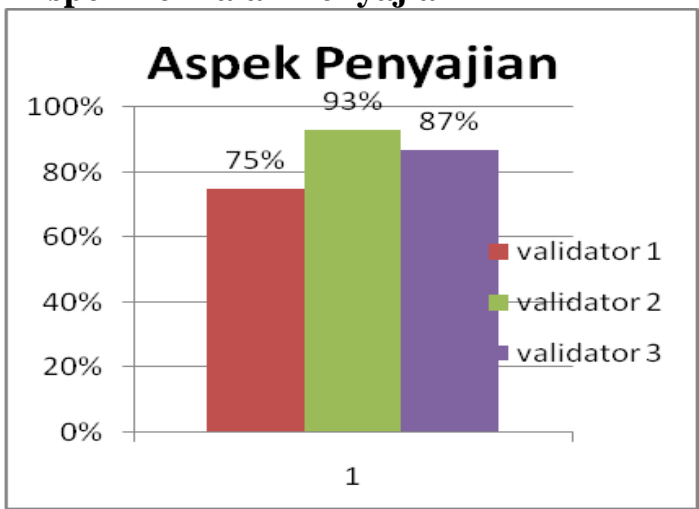

Gambar 3. Hasil Penilaian Aspek Penyajian

Berdasarkan hasil validasi penilaian aspek penyajian oleh ketiga ahli memperoleh kriteria "sangat valid" karena sudah sesuai dengan aspek penyajian dilihat dari alur yang digunakan dalam lembar kerja peserta didik yang rapi dan sesuai dengan apa yang dikonsepkan dari perencanaan dibagian depan lembar kerja peserta didik sebelum materi yaitu (Komponen CTL) dengan dibagian isi materi LKPD, keterlibatan peserta didik yang sudah ada didalam pembelajaran yaitu pada saat praktikum dan masyarakat belajar, komponen dalam LKPD yang runtut dimulai dari komponen CTL kontruktivisme, menemukan, bertanya, masyarakat belajar, pemodelan, refleksi, dan penilaian nyata.

\section{d. Aspek Penilaian Media}

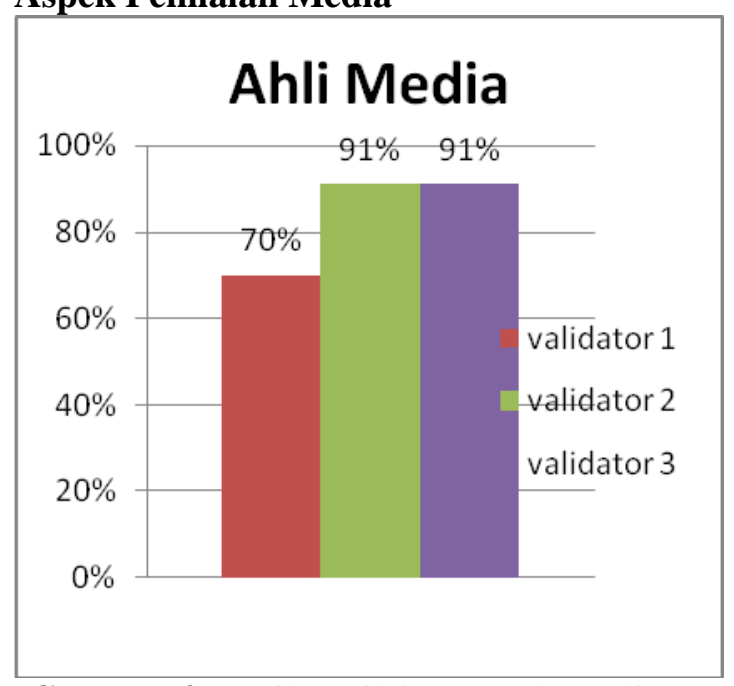

Gambar 4. Hasil Penilaian Aspek Media 
Berdasarkan hasil validasi penilaian aspek media oleh ketiga ahli memperoleh kriteria "sangat valid" karena sudah sesuai dengan aspek media dilihat dari lembar kerja peserta didik menggunakan kerta A4 serta penampilan tata letak pada lembar kerja peserta didik yang harmonis, sederhana dan konsisten, serta mudah dipahami karena kejelasan pada gambar yang ada.

\section{KESIMPULAN}

Berdasarkan hasil penelitian pengembangan lembar kerja peserta didik pendekatan contextual teaching learning untuk membangun kemampuan berpikir kritis peserta didik pada tema global warming yang telah dianalisis sesuai data yang diperoleh maka dapat disimpulkan bahwa:

1. Pengembangan lembar kerja peserta didik pendekatan Contextual Teaching Leaarning pada tema Global Warming dinyatakan dapat membangun kemampuan berpikir kritis melalui proses pendekatan Contextual Teaching Learning.

2. Kevalidan pengembangan lembar kerja peserta didik pendekatan Contextual Teaching Learning untuk membangun kemampuan berpikir kritis peserta didik tema Global Warming memperoleh kevalidan "sangat valid" dan dapat digunakan dengan sedikit revisi.

\section{DAFTAR PUSTAKA}

Burhanudin. T. R. (2016). Pendidikan Umun dalam Prespektif Pendidikan Islam dan Kewarganegaraan. Metode Ditaktik. vol 9 no 2.

Fatturrohman, M . (2012) Belajar dan pembelajaran Meningkatkan Mutu Pembelajaran Sesuai Standar Nasional. Yogyakarta: Teras

Ike Yuli, (2017). Pengembangan Perangkat Pembelajaran Terpadu Tipe Webbed Fokus IPA dengan Tema" Masyarakat Taneyan Lanjhang" pada Sekolah Dasar di Kabupaten Sumenep. Vol (3) no (1)
Majid, A. N. W. (2015). Pola Pembimbingan di Tempat Kerja: Studi Kasus Pelaksanaan Program Praktik Industri di PT JMI. Taman Vokasi, 3(2).

Marselina, dkk.(2020). Pembelajaran Terpadu Tipe Webbed untuk Meningkatkan Hasil Belajar Siswa Vol (8) no(3).

Prasmeswari, S.W, dkk. (2018). Inculcate Critical Thingking Skills In Primary Schools. SHES. Conferense Series. 1(1). 742-750.

Prastowo, A. (2011). Panduan Kreatif Membuat Bahan Ajar Inovatif Menciptakan Metode Pembelajaran yang Menarik dan Menyenangkan. Jogyakarta: DIVA Press.

Saputra, H. (2020). Kemampuan Berpikir Kritis Matematis. Lampung: Perpustakan IAI Agus Salim.

Shoidah, dkk. (2012). Pengembangan LKS Pendekatan Contextual Teaching and Learning Materi Hama dan Penyakit Tumbuhan. Jurnal BioEdu. Volume 1 (3): hal 8-12.

Sugiyono. (2017). Metode Penelitian Pendidikan Pendekatan Kuantitatif, Kualitatif, dan $R \& D$. Bandung: ALFABETA.

Sulistiani, E. dan Masrukan. (2016). Pentingnya Berpikir Kritis dalam Pembelajaran Matematika untuk Menghadapi Tantangan MEA. Seminar Nasional Matematika $X$. Universitas Negeri Semarang, Semarang.

Syahbana, A. (2012). Peningkatan Kemampuan Berpikir Kritis Matematis Peserta didik SMP Melalui Pendekatan Contextual Teaching And Learning. Edumatica, 2(1) , 45-57.

Yana, Royanah dkk (2019). Pengembangan Lembar Kerja Siswa (LKS) Menggunakan Ikon Kota Lubuk Linggau. Jurnal Pendidikan Matematika. Jurnal Education.Vol (2) No (2). 